\title{
KINERJA KUALITAS PELAYANAN PERIZINAN GANGGUAN USAHA DI KANTOR PELAYANAN PERIZINAN TERPADU KOTA GORONTALO
}

\author{
Sarfan Dj. Tabo \\ Universitas Gorontalo
}

\begin{abstract}
Performance Optimalisasi of aparatur for ever to improve the quality of goodness of aparatur quality and also itself giving of service. In anticipating constraint in Inwrought Peleyanan Permit hence done some step that is maximizing process service of permit to society either from service procedure facet, aparatur, and medium of prasana. According to Gronroos expressing the quality of service cover the Quality of function, Technical quality, Reputation Company. the prima Service will push society follow to participate in course of development.
\end{abstract}

Kata Kunci: Pelayanan, Perizinan, Terpadu,

\section{PENDAHULUAN}

Sebagai bagian dari sistem kenegaraan dengan konstitusi yang pekat dengan norma keadilan, ekonomi Indonesia dicirikan oleh ruang lingkup pelayanan yang sangat luas. Sayangnya, pelayanan yang menyentuh hampir setiap sudut kehidupan masyarakat tidak ditopang oleh mekanisme pengambilan keputusan yang terbuka serta proses politik yang demokratis. Karena itu tidak mengherankan jika pelayanan publik di Indonesia memiliki ciri yang cenderung korup, apalagi yang berkaitan dengan pengadaan produkproduk pelayanan yang bersifat perizinan dan lain-lain.

Kendati mungkin fenomena korupsi yang berkaitan dengan jenisjenis produk tadi hanya melibatkan biaya transaksi (antara sektor publik dengan individu masyarakat) yang relatif kecil (pretty corruption), tetapi biaya-biaya transaksi tersebut melibatkan porsi populasi yang sangat besar. Karena itu pola korupsi dengan menggunakan instrumen produkproduk pelayanan tersebut bisa jadi memiliki dampak yang sangat luas. Masalahnya kemudian adalah bagaimana meminimalkan biayabiaya transaksi tersebut? Teramat sulit tentunya menjawab pertanyaan ini, kendati jawabannya merupakan bagian terpenting dari strategi pemberantasan korupsi di sektor publik. Karena itu kajian mengenai mekanisme pelayanan perizinan, berikut biaya-biaya transaksinya menjadi elemen penting dari strategi pemberantasan korupsi.

Sejalan dengan itu, prinsip market oriented organisasi pemerintahan harus diartikan bahwa pelayanan yang diberikan oleh pemerintah (aparatur) harus mengutamakan pelayanan terhadap masyarakat. Demikian juga prinsip catalitic government, mengandung pengertian bahwa aparatur pemerintah harus bertindak sebagai katalisator dan bukannya penghambat dari kegiatan pembangunan, termasuk di dalamnya mempercepat pelayanan masyarakat. Dalam konteks ini, fungsi pemerintah lebih dititikberatkan sebagai regulator 
dibanding implementator atau aktor pelayanan. Sebagai imbangannya, pemerintah perlu memberdayakan kelompok-kelompok masyarakat sendiri sebagai penyedia atau pelaksanaan jasa pelayanan umum. Dengan kata lain, tugas pemerintah adalah membantu masyarakat agar mampu membantu dirinya sendiri (helping people to help themselves). Inilah sesungguhnya yang dimaksud dengan prinsip self-help atau steering rather than rowing.

\section{Pembentukan}

Kantor

Pelayanan Perizinan Terpadu (KPPT) sebagai institusi yang khusus bertugas memberikan pelayanan perizinan langsung kepada masyarakat, pada dasarnya dapat dikatakan sebagai terobosan baru atau inovasi manajemen pemerintahan di Daerah khususnya di Kota Gorontalo. Artinya, pembentukan organisasi ini hendaknya memberikan hasil berupa peningkatan produktivitas pelayanan umum dalam bidang perizinan gangguan. Pembentukan Kantor Pelayanan Perizinan Terpadu (KPPT) ini telah menghayati makna teori Reinventing Government.

Oleh karena itu, inovasi pembentukan Kantor Pelayanan Perizinan Terpadu (KPPT) ini perlu dikembangkan lagi dengan penemuan-penemuan baru dalam praktek manajemen pemerintahan di Daerah. Salah satu peluang yang dapat dikembangkan dalam hal ini adalah surat izin gangguan kedalam beberapa alternatif kualitas. Jenis pelayanan yang secara kualitatif lebih baik dapat dikenakan biaya yang agak mahal, sementara jasa pelayanan standar dikenakan biaya atau tarif yang standar pula. Pemasukan dari jenis pelayanan yang relatif mahal, akan dapat dipergunakan untuk membiayai pelayanan yang lebih murah, melalui mekanisme subsidi silang (cross subsidi). Dengan cara demikian, diharapkan institusi dapat membiayai sendiri kebutuhan operasionalnya, dengan tidak mengorbankan fungsi pelayanan yang menjadi tugas utamanya.

Selain itu, fenomena di atas juga menunjukkan bahwa masyarakat yang belum terlayani masih lebih besar dibandingkan masyarakat yang sudah terlayani. Kenyataan tersebut disebabkan selain karena faktor geografis juga oleh lemahnya pelayanan oleh petugas baik secara administratif maupun teknis. Untuk itu Kantor Pelayanan Perizinan Terpadu (KPPT) sebagai organisasi pelaksana harus meningkatkan kualitas pelayanan kepada pelanggan, karena pada hakikatnya kualitas ditentukan hanya oleh pelanggan (Coupet dalam Osborne dan Gaebler, 1992).

Kenyataan tersebut tidak saja disebabkan oleh berbagai hambatan sebagaimana disebutkan di atas, melainkan masih ada hal lain yang menjadi penyebabnya, seperti dalam memberikan pelayanan surat izin gangguan tidak diikuti oleh peningkatan kualitas birokrasi yang memberikan pelayanan kepada masyarakat.

Kita semua menyadari pelayanan perizinan selama ini sangat sulit untuk memahami pelayanan yang diselenggarakan oleh birokrasi publik. Masyarakat pengguna jasa sering dihadapkan pada begitu banyak ketidakpastian ketika mereka berhadapan dengan birokrasi. Amat sulit memperkirakan kapan pelayanan itu bisa diperolehnya. Begitu pula dengan harga pelayanan. Harga bisa berbeda-beda tergantung pada banyak faktor yang tidak sepenuhnya bisa dikendalikan oleh para pengguna jasa. 
Baik harga ataupun waktu seringkali tidak bisa terjangkau oleh masyarakat sehingga banyak orang yang kemudian malas berurusan dengan birokrasi publik.

Dari uraian diatas telah disebutkan bahwa keberadaan Kantor Pelayanan Perizinan Terpadu (KPPT) secara empirik telah berhasil mendongkrak efisiensi dan produktivitas pelayanan perizinan. Namun perlu digarisbawahi pula bahwa fungsi Kantor Pelayanan Perizinan Terpadu (KPPT) sesungguhnya tidak lebih sebagai penyelenggara pelayanan perizinan. Pada dasarnya penulisan tentang kinerja kualitas pelayanan perizinan ini penting untuk dilakukan, dikarenakan masyarakat sebagai customer service belum merasa puas baik dari segi waktu, biaya dan mutu pelayanan yang selama ini diberikan. Untuk itu penulisan ini ditujukan untuk meningkatkan kualitas pelayanan perizinan di Kantor Pelayanan Perizinan Terpadu (KPPT) Kota Gorontalo.

Tatalaksana pelayanan publik yang dilaksanakan di Kantor Pelayanan Perizinan Terpadu (KPPT) Kota Gorontalo meliputi:

1. Izin Gangguan (HO)

2. Surat Izin Usaha Perdagangan (SIUP)

3. Tanda Daftar Perusahaan (TDP)

4. Tanda Daftar Industri (TDI)

5. Izin Usaha Jasa Konstruksi (IUJK)

6. Izin Mendirikan Bangunan (IMB)

7. Surat izin Usaha Kepariwisataan (SIUK)

8. Surat Izin Usaha Angkutan (SIUA)

9. Surat Izin Penggunaan Petak (SIPP)
10. Surat Izin Penempatan

Total jenis izin yang ditangani adalah 10 (sepuluh) jenis pelayanan yang telah dikoordinasikan di Kantor Pelayanan Perizinan Terpadu (KPPT) Kota Gorontalo ini, pelaksanaannya tetap dikoordinasikan dengan unit kerja pengelolanya masing-masing. Hal yang berkaitan dengan persyaratan, mekanisme dan tata cara, jangka waktu penyelesaian dan biaya yang diperlukan, telah diatur sesuai dengan peraturan perundangundangan yang berlaku yang telah ditetapkan dalam Peraturan Daerah Kota Gorontalo.

Dalam pengelolaan naskah dinas berupa surat masuk dan keluar yang menjadi urusan Kantor Pelayanan Perizinan Terpad (KPPT) Kota Gorontalo mengikuti prinsip satu pintu, yaitu berpusat pada Tata Usaha (TU) Kantor Pelayanan Perizinan Terpadu (KPPT) Kota Gorontalo

Namun, dalam perjalanannya masih banyak dijumpai permasalahan yang berkaitan dengan pemberian pelayanan kepada masyarakat. Berbagai cerita atau pengalaman dari masyarakat sebagai pengguna dari pelayanan perizinan yang mengeluhkan terhadap pelayanan yang telah diberikan oleh Kantor Pelayanan Perizinan Terpadu (KPPT) Kota Gorontalo tersebut. Berdasarkan pernyataan permasalahan pokok tersebut di atas maka rumusan masaalah yang hendak dikaji, dalam pertanyaan penelitian (research question) sebagai berikut: Bagaimana Kinerja Kualitas Pelayanan izin Gangguan di Kantor Pelayanan Perizinan Terpadu dan faktor-faktor yang mempengaruhinya di Kota Gorontalo ?

\section{Manfaat penelitian}


1. Secara teoritis penulisan ini diharapkan mampu meningkatkan penguasaan teori-teori yang relevan dan pemahaman atas sejauhmana permasalahan yang diteliti serta penguasaan konsepkonsep dasar yang berhubungan dengan topik yang di teliti yaitu pada Kantor Pelayanan Perizinan Terpadu (KPPT) Kota Gorontalo dalam rangka meningkatkan kualitas pelayanan perizinan gangguan usaha pada kantor tersebut.

2. Secara praktis penulisan ini diharapkan mampu memberi sumbangan pemikiran atau bahan masukan bagi aparat Kantor Pelayanan Perizinan Terpadu (KPPT) Kota Gorontalo dalam meningkatkan kinerja kualitas pelayanan kepada masyarakat.

\section{Metode Penelitian}

Jenis penelitian ini adalah Library Research. Metode penelitian yang digunakan adalah deskriptif deduktif ke induktif, dengan teknik pengumpulan data yang di dapat dari bacaan literatur yang bersifat umum kehal-hal yang bersifat khusus. Sebelum pelaksanaan penelitian, terlebih dahulu dilakukan dengan persiapan diantaranya melaksanakan orientasi buku-buku bacaan dan sumber yang akurat.

Hal ini ditunjukkan untuk mendapatkan respon aparatur dalam meningkatkan kualitas pelayanan kepada masyarakat yang berdampak secara berarti terhadap kinerja mereka dalam pelayanan perizinan bagi kepentingan masyarakat.

Selanjutnya untuk menjawab permasalahan sebagaimana diungkapkan pada rumusan masaalah, digunakan teknik analisis deskriptif.

\section{Konsep Kinerja}

Kata kerja populer digunakan untuk menjelaskan hasil kerja yang dicapai oleh seseorang, kelompok ataupun organisasi sesuai dengan tugas, kewenangan yang dimiliki untuk mencapai tujuan organisasi. Padanan istilah kinerja diidentikkan dengan istilah perfomance. Menurut The Cribner-Bantanm English Dictionary (1997) terdapat keterangan sebagai berikut. Berasal dari akar kata "to perform" yang mempunyai beberapa padanan, berikut: (1) to door carry out; execute; (2) to diacharge or fulfill; as a vow; (3) to portray, as a character in a play; (4) to render by the voice or a musical instrument; (5) to execute or complete an undertaking; (6) to act a part in a play; (7) to perform music; (8) to do what is expectred of person or machine.

Arti padanan tersebut adalah (1) melakukan, menjalankan, melaksanakan; (2) memenuhi atau menjalankan kewajiban suatu nazar; (3) menggambarkan suatu karakter dalam suatu permainan; menggambarkan dengan suara atau alat musik; (5) melaksanakan atau menyempurnakan tanggung jawab; (6) melakukan suatu kegiatan dalam suatu permainan; (7) memainkan suatu pertunjukan musik; dan (8) melakukan sesuatu yang diharapkan oleh seseorang atau mesin.

Dalam hubungan dengan penelitian ini, maka padanan kata yang cocok digunakan adalah: (1) melakukan, menjalankan, melaksanakan; (2) memenuhi atau menjalankan nazar; (5) melaksanakan atau menyempurnakan tanggung jawab; (8) melakukan sesuatu yang diharapkan oleh orang atau mesin. Arti kata performance merupakan kata benda (noun) dimana 
salah satu padanan katanya adalah "thing done" (sesuatu hasil yang dikerjakan). Menurut Prawirosentono (1999) performance atau kinerja adalah hasil kerja yang dapat dicapai oleh seseorang atau sekelompok orang dalam organisasi, sesuai dengan wewenang dan tanggung jawab masing-masing, dalam rangka upaya mencapai tujuan organisasi bersangkutan secara legal, tidak melanggar hukum dan sesuai dengan moral maupun etika.

$$
\text { Dalam Kamus Bahasa }
$$

Indonesia senidri, sampai edisi sekarang kata kinerja belum tercantum. Istilah-istilah yang sering dipakai yang berkaitan dengan kinerja adalah efisien, efektivitas dan bahkan Frederickson (1984) menambahkan keadilan sosial untuk menilai apakah administrasi negara telah berhasil mengemban misinya sebagai isntrumen publik untuk meningkatkan kesejahteraan masyarakat. Gaspersz (1997) mengatakan bahwa kinerja dibangun dari kualitas, dan kualitas adalah terdiri dari segala sesuatu yang bebas dari kekurangan atau kerusakan yang dihasilkan oleh organisasi untuk memuaskan semua unsur yang berkaitan dengan organisasi baik internal maupun eksternal.

Mengacu pada pengertian diatas, bahwa unsur pembentuk kinerja organisasi adalah terdiri atas: efisiensi, efektivitas, kualitas dan keadilan, maka dapat didefinisikan bahwa kinerja organisasi adalah: "hasil kerja yang secara akumulatif dicapai oleh organisasi berdasarkan sasaran yang ditetapkan untuk mencapai tujuan yang ditentukan sebelumnya".

\section{Kualitas Pelayanan}

David Garvin, (dalam Yamit, 2005,9) mengidentifikasikan lima pendekatan perspektif kualitas yang dapat digunakan oleh para praktisi bisnis, yaitu :

\section{Transcendental Approach}

Kualitas dalam pendekatan ini adalah sesuatu yang dapat dirasakan, tetapi sulit didefinisikan dan dioperasionalisasikan maupun diukur. Perspektif ini umumnya diterapkan dalam karya seni seperti musik, seni tari, seni drama dan seni rupa. Dimana untuk produk dan jasa pelayanan, perusahaan dapat mempromosikan dengan menggunakan pernyataanpernyataan seperti kelembutan dan kehalusan kulit (sabun mandi), kecantikan wajah (kosmetik), pelayanan prima (bank) dan tempat berbelanja yang nyaman (mall). Definisi seperti ini sangat sulit untuk dijadikan sebagai dasar perencanaan dalam manajemen kualitas.

\section{Product-based Approach}

Kualitas dalam pendekatan ini adalah suatu karakteristik atau atribut yang dapat diukur. Perbedaan kualitas mencerminkan adanya perbedaan atribut yang dimiliki produk secara objektif, tetapi pendekatan ini dapat menjelaskan perbedaan dalam selera dan preferensi individual.

\section{User-based Approach}

Kualitas dalam pendekatan ini didasarkan pada pemikiran bahwa kualitas tergantung pada orang yang memandangnya, dan produk yang paling memuaskan 
preferensi seseorang atau cocok dengan selera (fitnes for used) merupakan produk yang berkualitas paling tinggi. Pandangan yang subjektif ini mengakibatkan konsumen yang berbeda memiliki kebutuhan dan keinginan yang berbeda pula, sehingga kualitas bagi seseorang adalah kepuasan maksimum yang dapat dirasakannya.

\section{Manufacturing-based Approach} Kualitas dalam pendekatan ini adalah bersifat supply-based atau dari sudut pandang produsen yang mendefinisikan kualitas sebagai sesuatu yang sesuai dengan persyaratannya (conformance quality) dan prosedur. Pendekatan ini berfokus pada kesesuaian spesifikasi yang ditetapkan perusahaan secara internal. Oleh karena itu, yang menentukan kualitas adalah standar-standar yang ditetapkan perusahaan, dan bukan konsumen yang menggunakannya.

\section{Value-based Approach}

Kualitas
pendekatan ini $\begin{array}{r}\text { dalam } \\ \text { adalah }\end{array}$
memandang kualitas dari segi
nilai dan harga. Kualitas
didefinisikan sebagai "affordable
excellence", oleh karena itu
kualitas dalam pandangan ini
bersifat relatif, sehingga produk
yang memiliki kualitas paling
tinggi belum tentu produk yang
paling bernilai. Produk yang
paling bernilai adalah produk
yang paling tepat dibeli.
Meskipun sulit mendefinisikan
alitas dengan tepat dan tidak ada
finisi kualitas yang dapat diterima
cara universal, dari perspektif

David Garvin tersebut dapat bermanfaat dalam mengatasi konflikkonflik yang sering timbul diantara para manajer dalam departemen fungsional yang berbeda. Misalnya, departemen pemasaran lebih menekankan pada aspek keistimewaan, pelayanan, dan fokus pada pelanggan. Departemen perekayasaan lebih menekankan pada aspek spesifikasi dan pada pendekatan product-based. Sedangkan departemen produksi lebih menekankan pada aspek spesifikasi dan proses. Menghadapi konflik seperti ini sebaiknya pihak perusahaan menggunakan perpaduan antara beberapa perspektif kualitas dan secara aktif selalu melakukan perbaikan yang berkelanjutan atau melakukan perbaikan secara terus menerus.

\section{Definisi Kualitas Jasa Pelayanan}

Kualitas jasa pelayanan sangat dipengaruhi oleh harapan konsumen. Harapan konsumen dapat bervariasi dari konsumen satu dengan konsumen lain walaupun pelayanan yang diberikan konsisten. Kualitas mungkin dapat dilihat sebagai suatu kelemahan kalau konsumen mempunyai harapan yang terlalu tinggi, walaupun dengan suatu pelayanan yang baik. Menurut Wyckof dalam Lovelock (yang dikutip dari Nursya'bani, 2006, 19) memberikan pengertian kualitas layanan sebagai tingkat kesempurnaan tersebut untuk memenuhi keinginan konsumen, sedangkan menurut Parasuraman, etal Kualitas layanan merupakan perbandingan antara layanan yang dirasakan (persepsi) konsumen dengan kualitas layanan yang diharapkan konsumen. Jika kualitas layanan yang dirasakan sama atau 
melebihi kualitas layanan yang diharapkan, maka layanan dikatakan berkualitas dan memuaskan.

Menurut Gronroos (dalam Purnama, 2006,20) menyatakan kualitas layanan meliputi :

1. Kualitas fungsi, yang menekankan bagaimana layanan dilaksanakan, terdiri dari : dimensi kontak dengan konsumen, sikap dan perilaku, hubungan internal, penampilan, kemudahan akses, dan service mindedness.

2. Kualitas teknis dengan kualitas output yang dirasakan konsumen, meliputi harga, ketepatan waktu, kecepatan layanan, dan estetika output.

3. Reputasi perusahaan, yang dicerminkan oleh citra perusahaan dan reputasi di mata konsumen.

Dari definisi-definisi tersebut diatas dapat disimpulkan bahwa kualitas pelayanan adalah tingkat keunggulan pelayanan yang dapat memenuhi keinginan konsumen/ pelanggan yang diberikan oleh suatu organisasi.

\section{Hasil Penelitian dan Pembahasan}

Deskripsi hasil penelitian ini adalah : berdasarkan uraian-uraian sebagaimana dikemukakan diatas bahwa Prosedur kerja merupakan suatu pola tetap dari rangkaian tata kerja yang berkaitan satu sama lain sehingga menunjukan adanya suatu aturan tahap demi tahap secara jelas dan pasti serta jalan yang harus ditempuh dalam rangka penyelesaian bidang tugas.

Berbicara prosedur pelayanan secara teori maupun melalui kebijakan-kebijakan pemerintah, agar memperhatikan unsur-unsur pelayanan. Dari beberapa unsur pelayanan, salah satunya adalah unsur kesederhanaan. Pada kantor Pelayanan Perizinan Terpadu Kota Gorontalo memiliki alur atau mekanisme yang digunakan sebagai acuan penyelenggara perizinan yang berjumlah 10 ( sepuluh ) jenis izin.

Adapun mekanisme dari alur pelayanan perizinan pada kantor Pelayanan Perizinan Terpadu Kota Gorontalo sebagai berikut:

\section{Gambar 1.Mekanisme Alur Pelayanan}

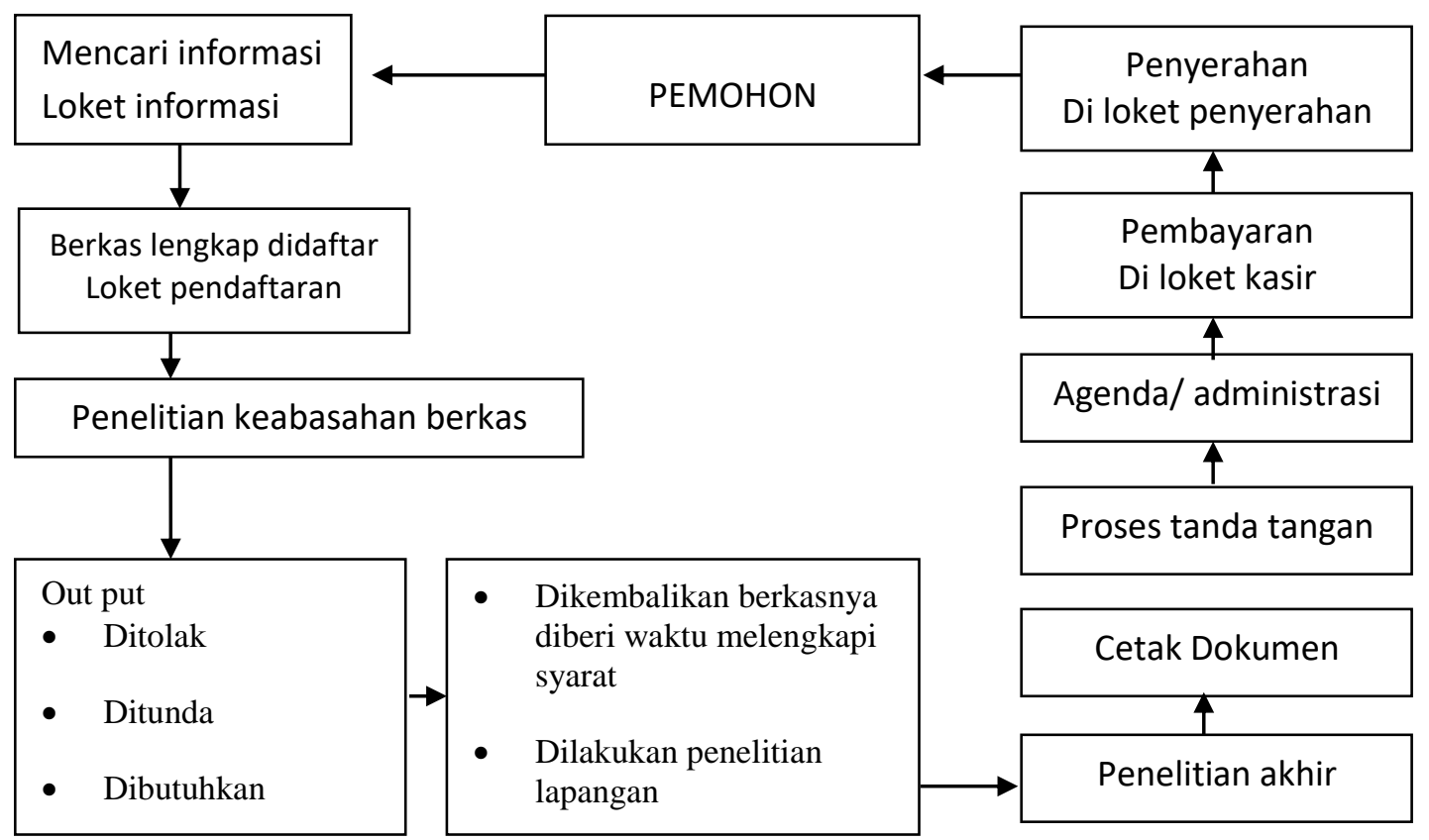


Dari hasil pengamatan yang dilakukan diperoleh bahwa prosedur yang dilaksanakan saat ini di KPPT dirasakan masyarakat alur birokrasinya masih panjang. Hal ini dibuktikan dengan masih dilakukannnya peninjauan lapangan yang kadang - kadang masih menunggu kehadiran Tim Teknis yang merupakan personil dari SKPD teknis yang ditugaskan untuk menilai layak tidaknya usaha yang mengurus perizinan.

Untuk mendapat Izin Gangguan pada Kantor Pelayanan Perizinan Kota Gorontalo , Pemohon diwajibkan melampirkan beberapa persyaratan. Adapun yang diwajibkan adalah sebagai berikut :

1. Foto Copy Kartu Tanda Penduduk (KTP)

2. Foto copy Pelunasan PBB Tahun berjalan

3. Foto copy Izin Mendirikan Bangunan ( IMB )

4. Foto copy Akta Perusahaan bila berbadan hukum

5. Materai 60001 lembar

6. Surat Keterangan usaha dari kelurahan

7. Foto copy sertifikat tanah

8. Foto copy pajak reklame tahun berjalan

9. Pas photo $3 \times 4$

10. Permohonan Izin gangguan yang ditandatangani oleh tetangga sebagai persetujuan dibukanya usaha tersebut yang dilengkapi dengan foto copy KTP tetangga, sket lokasi serta ditanda tangani oleh Lurah dan Camat setempat.

Izin Gangguan merupakan

pemberian izin tempat, usaha / kegiatan kepada orang pribadi atau badan dilokasi tertentu yang dapat menimbulkan bahaya, kerugian dan gangguan, tidak termasuk tempat usaha / kegiatan yang telah ditentukan oleh Pemerintah Daerah. Dalam hal pemungutan retribusi izin gangguan Kantor Pelayanan Perizinan Terpadu Kota
Gorontalo mengacu pada Peraturan Walikota Gorontalo Nomor 18 Tahun 2011 tentang Retribusi Izin Gangguan, dimana besarnya tarif retribusi ditetapkan berdasarkan tarif dasar Retribusi dikalikan hasil penjumlahan antara indeks lokasi, indeks luas, indeks modal, indeks gangguan

Perhitungan untuk menentukan besarnya tariff retribusi sebagai berikut :

\section{Rumus :}

Tarif Dasar x ( indeks letak + Indeks Luas + Indeks Modal + indeks Gangguan )

a. Tarif Dasar Retribusi:Rp. 75.000

b. Indeks Letak Jalan Negara indeksnya $\quad: 5$ Jalan Provinsi indeksnya : 4 Jalan kota indeksnya $\quad: 3$

Jalan kelurahan indeksnya : 2 Jalan lingkungan indeksnya : 0

c. Indeks Luas

$>$ Ruang Terbuka

Luas diatas $100 \mathrm{M} 2 \quad: 10$

Luas diatas $75-100 \mathrm{M} 2 \quad: 5$

Luas diatas $50-75 \mathrm{M} 2 \quad: 4$

Luas diatas $25-50 \mathrm{M} 2 \quad: 3$

Luas diatas 10-25 M2 : 2

Luas lebih kecil $10 \mathrm{M} 2 \quad$ : 1

$>$ Ruang Tertutup

Luas diatas $1000 \mathrm{M} 2 \quad: 10$

Luas diatas $500-1000 \mathrm{M} 2: 7$

Luas diatas $250-500 \mathrm{M} 2$ : 5

Luas diatas $100-250 \mathrm{M} 2 \quad: 3$

Luas lebih kecil 100 M2 : 1

d. Indeks Modal

Modal diatas 500 Juta $\quad: 15$

Modal diatas $400-500$ juta : 13

Modal diatas 300-400 Juta : 10

Modal diatas 200-300 Juta : 7

Modal diatas $100-200$ Juta : 5

Modal diatas 50-100 Juta : 3

Modal diatas $10-50$ juta $\quad: 1$ 


$\begin{array}{ll}\text { Modal dibawah 10 juta } & : 0 \\ \text { e. Indeks Gangguan } & : \\ \text { Gangguan sangat tinggi } & : 15 \\ \text { Gangguan tinggi } & : 10 \\ \text { Gangguan sedang } & : 7 \\ \text { Gangguan kecil } & : 5 \\ \text { Gangguan sangat kecil } & : 0 \\ \text { Bentuk apapun } & \text { institusi }\end{array}$

pelayanananya, maka yang terpenting adalah bagaimana memberikan bantuan dan kemudahan kepada masyarakat dalam rangka memenuhi kebutuhan dan kepentingannya. Keterkaitannya dengan penyelenggaraan pemerintahan, birokrasi sebagai ujung tombak pelaksana pelayanan publik mencakup berbagai program-program pembangunan dan kebijaksanaankebijaksanaan pemerintah.

Suatu sistem yang efektif dalam tataran organisasi publik, di samping mendorong karyawan untuk menampilkan kinerja yang memuaskan dan tingkat produktivitas yang tinggi, juga harus mencerminkan kesediaan manajemen untuk menghargai perilaku positif yang diinginan karyawan dan organisasi public tersebut. Artinya, di samping kinerja dan produktivitas kinerja, suatu system imbalanpun harus merupakan penghargaan terhadap kesetiaan, pengalaman, kesediaan memikul tanggung jawab yang lebih besar, prakarsa, kreativitas, inovasi dan perilaku positif lain yang jelas.

Penyelenggaraan pelayanan perizinanan di KPPT Kota Gorontalo tidak terlepas dari optimalisasi kinerja aparatur untuk senantiaya meningkatkan kualitas baik aparatur itu sendiri maupun kualitas pemberian pelayanan. Proses dalam pemberian pelayanan kepada masyarakat merupakan tugas dan fungsi aparatur dalam bekerja. Artinya, pemahaman aparatur harus dilayani berubah menjadi aparatur yang melayani, hal tersebut merupakan langkah pembaharuan atau perubahan birokrasi pemerintahan dalam pemberian pelayanan yang mencakup makna redefinisi birokrasi, restrukturisasi, refungsionalisasi dan reposisi berbagai unsur dalam kehidupan birokrasi pemerintahan. Pembahasan reformasi birokrasi pemerintahan dalam hal tersebut, terkait dengan proses perubahan perilaku aparatur birokrasi agar dapat menjawab paradigma baru dalam menangani persoalan yang ada terkait dengan pemenuhan kebutuhan masyarakat dalam mengedepankan pelayanan.

Pelaksanaan tugas aparatur dalam pemberian serta meningkatkan pelayanan yang ada di KPPT Kota Gorontalo tersebut, proses pencapai kinerjanya senantiasa dilandaskan pada Prosedur yang ada, berupa peraturan-peraturan baku yang didalamnya mencakup dasar hukum, maksud dan tujuan, klasifikasi sasaran dan standar biaya dalam merealisasikan pelayanan perizinan khususnya pelayanan Adapun dasar hukum yang dimaksud adalah Perda No. 18 Tahun 2011 tentang Izin Gangguan . Adapun sasaran yang tercantum dalam Keterkaitannya dengan aparatur KPPT Kota Gorontalo dalam meningkatkan pencapaian kinerja serta kualitas pelayanan perizinan khususnya pelayanan Izin Gangguan terangkum dalam janji layanan atau komitmen kerja yang disepakati bersama yang dimaksudkan untuk memacu semangat bekerja aparatur pelayanan perizinan dalam menjalankan tugas sesuai dengan Standar Pelayanan dan Prosedur Tetap, guna memproses perizinan dengan cepat, mudah, transparan dan pasti, memberikan pelayanan dengan ramah, cermat dan propesional.

Salah satu strategi aparatur KPPT Kota Gorontalo dalam pencapai kinerja yang maksimal yaitu, proses yang digunakan dalam meningkatkan kualitas pelayanan perizinan khususnya Izin Gangguan dapat dilihat atau memiliki alat ukur berupa realisasi dokumen izin dan realisasi retribusi. Namun, penekanan diKPPT lebih kepada kualitas dokumen izin, dalam arti 
meningkatkan kualitas Izin Gangguan . ada beberapa indikator yang biasanya digunakan untuk mengukur kinerja birokrasi publik (Dwiyanto, 1995), yaitu sebagai berikut.

\section{Produktivitas}

Konsep produktivitas tidak hanya mengukur tingkat efisiensi, tetapi juga efektivitas pelayanan. Produktivitas pada umumnya dipahaini sebagai rasio antara input dengan output. Konsep produktivitas dirasa terlalu sempit dan kemudian General Accounting Office (GAO) mencoba mengembangkan satu ukuran produktivitas yang lebih luas dengan memasukkan seberapa besar pelayanan publik itu memiliki hasil yang diharapkan sebagai salah satu indikator kinerja yang penting.

\section{Kualitas Layanan}

Isu mengenai kualitas layanan cenderung menjadi semakin penting dalam menjelaskan kinerja organisasi pelayanan publik. Banyak pandangan negatif yang terbentuk mengenai organisasi publik muncul karena ketidakpuasan masyarakat terhadap kualitas layanan yang diterima dan organisasi publik. Dengan deinikian, kepuasaan masyarakat terh.dap Lyanan dapat dijadikan indikator kinerja organisasi publik. Keuntungan utama menggunakan kepuasan masyarakat sebagai indikator kinerja adalah informasi mengenai kepuasan masyarakat seringkali tersedia secara mudah dan murah.

Informasi mengenai kepuasan terhadap kualitas pelayanan seringkali dapat diperoleh dan media massa atau diskusi pubilk. Akibat akses terhadap informasi mengenai kepuasan masyarakat terhadap kualitas layanan relatif sangat tinggi, maka bisa menjadi satu ukuran kinerja organisasi publik yang mudah dan murah dipergunakan. Kepuasan masyarakat bisa menjadi parameter untuk menilai kinerja organisasi publik.

3. Responsivitas

Responsivitas adalah kemampuan organisasi untuk mengenali kebutuhan masyarakat, menyusun agenda dan prioritas pelayanan, dan mengembangkan program-program pelayanan publik sesuai dengan kebutuhan dan aspirasi masyarakat. Secara singkat responsivitas di sini menunjuk pada keselarasan antara program dan kegiatan pelayanan dengan kcbutuhan dan azpirasi.

Berdasarkan keputusan Menteri pendayagunaan aparatur Negara Nomor 63 tahun 2003 tentang pedoman umum penyelenggaraan pelayanan publik seperti prosedur pelayanan, persyaratan pelayanan, kemampuan petugas pelayanan, kepastian biaya pelayanan, kecepatan pelayanan, keadilan mendapatkan pelayanan dan kepastian jadwal pelayanan maka pemerintah dituntut untuk meningkatkan pelayanan masyarakat serta peningkatan kemampuan sumberdaya aparatur. Menurut Ridwan (2009:163) ada beberapa hambatan yang biasanya dikeluhkan oleh masyarakat yang ingin mengurus perizinan yaitu:

a. Biaya perizinan

1. Biaya pengurusan izin sangat memberatkan bagi pelaku usaha kecil. Besarnya biaya perizinan seringkali tidak transparan

2. Penyebab besarnya biaya disebabkan karena pemohon tidak mengetahui besar biaya resmi utuk pengurusan izin, dan kerana adanya pungutan liar.

b. Waktu

1. Waktu yang diperlukan mengurus izin relatif lama karena prosesnya yang berbelit-belit

2. Tidak adanya kejelasan kapan izin diselesaikan.

3. Proses perizinan tergantung pada pola birokrasi setempat

c. Persyaratan

1. Persyaratan yang ditetapkan seringkali sulit untuk diperoleh

2. Persyaratan yang diminta secara berulang-ulang untuk berbagai jenis izin.

Dalam kaitannya dengan pelayanan pemberian izin Gangguan, diharapkan 
praktek pelayanan perizinan tersebut dapat memenuhi tujuan yang telah ditetapkan terutama dalam hal penyederhanaan prosedur. Kepemiikan usaha sering merasa prosedur perizinan cukup berbelit-belit serta penetapan biaya yang masih diangap sangat tinggi untuk mengurus izin tersebut bagi masyarakat yang tidak mampu. Keresahan itu sebenarnya berujung pada kurangnya sosialisasi tentang Izin Gangguan, karena Izin Gangguan adalah merupakan izin yang berikan kepada orang atau badan hukum yang berusaha serta berfungsi sebagai jaminan kepastian Hukum atas usaha tersebut.

Oleh sebab itu dalam kaitannya terhadap pelayanan perizinan khususnya Izin Gangguan pemerintah harus menetapkan standar pelayanan yang optimal antara lain aparatur pemerintah harus dapat meningkatkan pengetahuan dan profesionalitas, guna mengubah citra aparatur yang sebelumnya di pandang lamban menjadi efisien dan efektif sesuai dalam meningkatkan pelayanan kepada masyarakat Pada dasarnya harapan masyarakat terhadap proses perizinan tidak berbeda dengan harapan pemerintah, yakni sederhana, murah, adanya kepastian waktu, pelayanan yang berkualitas dan sah secara hukum. Dari sisi masyarakat, murah berarti biaya yang wajar dan dapat di jangkau. Kepastian waktu merupakan elemen penting lainnya yang diharapkan masyarakat dari pemerintah. Kepastian tersebut menyangkut masalah lamanya waktu yang dibutuhkan untuk proses pengurusan serta kapan izin dapat dikeluarkan.

Pada Kantor Pelayanan Perizinan Terpadu Kota Gorontalo ada beberapa faktor penghambat dalam memberikan pelayanan perizinan khususnya Izin Gangguan yakni :

1. Belum dilakukan pola pelayanan prima yaitu mengenai kejelasan waktu pengurusan izin gangguan yang melenceng dari waktu yang telah di tetapkan yakni 3 hari, menurut wawancara dengan instansi terkait bahwa keterlambatan tersebut terjadi akibat aparat yang bertugas masih belum proposional jika dibandingkan dengan beban kerja yang ada. hal ini terjadi dikarenakan belum adanya pendidikan dan pelatihan khusus pelayanan bagi sebagian besar aparatur yang ditempatkan pada Kantor Pelayanan Perizinan Terpadu Kota Gorontalo.

2. Kurangnya sarana dan prasana

Sarana dan prasarana adalah salah satu faktor pendukung yang sangat berpengaruh dalam rangka upaya meningkatkan kualitas kinerja pelayanan perizinan. Kita dapat memungkiri bahwa kemampuan yang dimiliki oleh aparat tidak dapat dimanfaatkan semaksimal mungkin apabila sarana dan prasarana tersebut sangatlah kurang . Hal ini berdampak buruk terhadapat kinerja aparat dalam melaksanakan tugas tugasnya.

Dikantor Pelayanan Perizinan Terpadu kota Gorontalo berdasarkan pengamatan dan hasil wawancara yang dilakukan menunjukan sarana dan prasarana dikantor tersebut belum memadai misalnya seperti komputer yang digunakan untuk proses penyelesaian ijin hanya 2 ( dua ) buah untuk 10 (sepuluh ) jenis ijin hal ini sangat menghambat proses penyelesaian dari izin izin tersebut dan ditambah lagi tidak terdapat generator sebagai alternatif apabila lampu dari PLN padam sehingga izin - izin tidak dapat diselesaikan tepat waktu.

3. Terbatasnya aparatur pelaksana

Aparatur dikantor Pelayanan Perizinan Terpadu masing - masing orang telah diberikan tugas dan tanggung jawab pekerjaan sehari - hari namun aparatur yang ditempatkan pada seksi perizinan khususnya proses pencetakan 
izin masih sangatlah kurang, mengingat apabila yang bersangkutan berhalangan hadir tidak ada yang menggantikan posisi tersebut, hal ini pula yang menjadi faktor hambatan dalam proses penyelesaian perizinan.

Faktor - faktor penghambat tersebut diatas berusaha diperbaiki oleh Kantor Pelayanan Perizinan Terpadu Kota Gorontalo dengan langkah - langah sebagai berikut :

1. Aparatur yang ada pada Kantor Pelayanan Perizinan Terpadu Kota Gorontalo akan diupayakan untuk mengikuti pendidikan dan latihan khusus dibidang pelayanan, dan untuk memberikan kejelasan waktu penyelesaian izin diruangan tunggu pada KPPT telah dipasang standar waktu pelayanan dan hal ini yang akan menjadi acuan dan motivasi pegawai untuk menyelesaikan izin tepat waktu sesuai dengan Sistem dan Prosesur Pelayanan Perizinan Nomor 5 Tahun 2007.

2. Kantor Pelayanan Perizinan Terpadu Kota Gorontalo pada anggaran tahun 2013 ini telah menyediakan dana untuk pembelian komputer dan generator guna kelancaran proses penyelesaian izin.

3. Aparatur yang ditempatkan pada seksi perizinan khususnya bagian pencetakan izin memang masih kurang mengingat aparatur yang ditempatkan di KPPT ini masih ada yang belum bisa mengoperasikan komputer, sehingga saat ini pihak KPPT telah mengusulkan ke BKD dan Diklat Gorontalo tenaga yang mampu mengoperasikan komputer sehingga penyelesaian izin bisa semaksimal mungkin.

\section{Kesimpulan}

Berdasarkan penilaian dan pembahasan dapat diambil beberapa kesimpulan sebagai berikut :
1. Penyelenggaraan pelayanan perizinanan di KPPT Kota Gorontalo tidak terlepas dari optimalisasi kinerja aparatur untuk senantiaya meningkatkan kualitas baik aparatur itu sendiri maupun kualitas pemberian pelayanan. Proses dalam pemberian pelayanan kepada masyarakat merupakan tugas dan fungsi aparatur dalam bekerja. Artinya, pemahaman aparatur harus dilayani berubah menjadi aparatur yang melayani, hal tersebut merupakan langkah pembaharuan atau perubahan birokrasi pemerintahan dalam pemberian pelayanan yang mencakup makna redefinisi birokrasi, restrukturisasi, refungsionalisasi dan reposisi berbagai unsur dalam kehidupan birokrasi pemerintahan.

2. Pelayanan yang prima tersebut akan mendorong masyarakat ikut berparisipasi dalam proses pembangunan. Dengan demikian akan mengarah pada peningkatan produktifitas dan peningkatan taraf hidup masyarakat. Namun pada pelaksanaan sering terjadi hambatan-hambatan dalam memberikan pelayanan kepada masyarakat. Hal ini disebabkan oleh hal-hal sifatnya teknis dan non teknis yang dapat mempengaruhi kinerja aparatur, misalnya penyediaan fasilitas pelayanan yang terbatas, dan kurangnya kemampuan dalam mengemban tugasnya. Hal ini merupakan tantangan bagi aparat, yang merupakan ujung tombak penyelenggaraan pemerintahan didaerah yang berhadapan langsug dengan masyarakat.

3. Sehubungan dengan kendala yang dihadapi oleh Kantor Peleyanan Perizinan Terpadu Kota Gorontalo dalam meningkatkan kualitas kinerja pelayanan izin gangguan, maka dilakukan beberapa langkah yaitu memaksimalkan proses pelayanan perizinan kepada masyarakat baik dari 
segi prosedur pelayanan, aparatur, sarana dan prasana.

\section{DAFTAR PUSTAKA}

Barata, Atep Adya. 2003. Dasar - Dasar Pelayanan Prima. Jakarta : PT Elex Media Komputindo.

Badan Pusat Statistik Kota Gorontalo Tahun 2012, Kota Gorontalo Dalam Angka 2012, Badan Pusat statistik Kota Gorontalo, Kota Gorontalo.

Buana, A. P., Aswari, A., Said, M. F., \& Arifin, M. Y. R. 2018. Responsibility Parking Service Business to The Protection Of Consumer Of The Parking Services in Makassar. Substantive Justice International Journal of Law, 1(1), 23-32.

Gaspersz, Vincent, Manajemen Kualitas (Penerapan Konsep-konsep Kualitas Dalam Manajemen Bisnis Total), Gramedia Pustaka Utama, Jakarta, 1997.

Gibson, dkk., Organisasi: Perilaku, Struktu dan Proses,Binarupa Aksara, Jilid I \& II, Jakarta, 1996.

Haselbein, Frances, Marshall Goldsmith, Ricard Beckhard, The Organization of The Future (Organisasi MAsa Depan), PT Elex Media Komputindi, Jakarta, 1997.

Henry, Nicholas, Administrasi Negara dan Masalah-masalah Publik, Rajawali Press, Jakarta 1995.

Kartaningsih, Elis, Gagasan Penilaian Kinerja Pelayanan Umum:Institusi Mekanisme dan Instrumen Penilaian, Jurnal Wacana Kinerja, No. 4 Thn 1, LAN Jawa Barat, 1999.

Kartasasmita, Ginanjar, Administrasi Pembangunan, LP3ES, Jakarta, 1997.
Pembangunan untuk Rakyat (Memadukan Pertumbuhan dan Pemerataan), CIDES, Jakarta, 1996.

Kerlinger, Fred, N, Asas-asas Penelitian Behavioral, Gadjah Mada University Press, Yogyakarta, 1995.

Korten, Frances, F., Robert Y., Siy, Jr., 1998, Transforming a Bureaucracy (the Experience of the Philipine National Irrigation Administration), Ateneo De Manila University Press.

Kristiadi, J.B, Persfektif Administrassi Publik Menghadapi Tantangan Abad 21, Jurnal Administrasi dan Pembangunan, Edisi, Khusus, Volume I No. 2, 1997.

Administrasi/Manajemen Pembangunan, LAN, Jakarta, 1994.

Siagian, P.Sondang. (1996). Manajmen Sumber Daya Manusia. Bumi Aksara. Jakarta.

Miles, Matthew B dan A Michael Huberman. 1992. Analisis Data Kualitatif. Diterjemahkan oleh Tjejep Rohendi Rohidi. UIP. Jakarta.

Moenir. 2001. Manajemen Pelayanan Umum Di Indonesia. Jakarta : PT. Bumi Aksara

Muhammad Fachri Said, 2015. Pengelolaan Dan Pemanfaatan Sumber Daya Perikanan Laut Indonesia, AlIshlah Fakultas Hukum, Universitas Muslim Indonesia, 17 (1), 170-182

Ridwan, Juniarso. 2009. Hukum Administrasi Negara dan Kebijakan Pelayanan Publik. Bandung : Nuansa.

Ratminto dan Atik Septi Winarsih. 2005. Manajemen Pelayanan. Yogyakarta : Pustaka pelajar.

Widodo, Joko, 2001, Good Governance Telaah dari Dimensi Akuntabilitas dan Control Birokrasi pada era desentralisasi dan Otonomi daerah, Surabaya :Insani Cendiki 